\title{
Influence on Educator's Attitude to Educated Target under Ideological and Political Education
}

\author{
Wei WANG \\ Student Affairs Office, North China University of Technology, Beijing, China
}

\begin{abstract}
Positive mental quality can prevent individual psychosomatic disorders, enhance physical and mental health, plays a vital role in the harmonious development of individuals. Positive psychological quality training of college counselors, to promote the construction of college counselors team, has the vital significance to strengthen and improve the ideological and political education of College students. Ideological and political educator's attitude influence plays an important role in education. Ideological and political educator, education information, education target and education environment are four factors to affect education attitude changing of educated target. In this paper, we will study the influence of the ideological and political educators to the educated object, in order to show this role in the ideological and political education.

KEYWORD: ideological and political education; education's attitude; influence on the educated target
\end{abstract}

\section{INTRODUCTION}

With the rapid development of the Internet and information technique, Networking becomes an important means of obtaining and dissemininating information, it has a unique advantage for us to obtain knowledge. However, in the face of multicultural integration, sense conflict of worth, it is the important task for the University Ideological and political education to cultivate their own capacity to identify all kinds of information and to resist different bad information and how college students strengthen moral self-discipline, especially in the face of the development of network culture. Meanwhile, we also realize that not only the internet has brought us a good opportunity

Counselor is the backbone to carry out ideological and political education of college students, is the university student ideological and political education and daily management work of the organizers, practitioners and instructors." College Counselors' psychological quality is an important resource, directly affect the effective development of daily ideological and political education of College students. Positive psychological quality training of college counselors, is to strengthen the need of university counselor team construction, is to improve the Counselor's personality, the need to promote the development of students' personality health, also need to enhance the effectiveness of Ideological and political education of college students.

\subsection{The connotation and function of positive psychological quality}

"Standard for classification of positive psychological quality" was formerly only in the psychological quality has positive and negative effects under the elaborate, positive psychology appears, as the implementation of positive psychology focus on the core research content of the ultimate goal of human happiness, and reflect the positive psychology to actively prevent this core idea, positive psychological quality began to appear as a fixed terms. Therefore, the definition of positive psychological quality should be carried out in the perspective of positive psychology.

Positive psychology stresses not only to various problems of people or the society all positive forces, as well as study and positive quality, such as the positive emotional experience, positive personality, positive social organizational system and so on. Positive psychological quality is an important content of the positive psychology research.

American psychologist Alan Carr proposed a measure of positive psychological quality is a good psychological quality, need to meet two criteria: first, "is the quality of life and well-being, realize the associated; meet the moral value, does not damage the interests of others, by the public agency will sure have value in high society role; can be great achievements. As his reason for success example." Second, and most important standard, namely psychological quality power contrary to every 
positive mental quality should not be the same meaning has positive value significance. Then Peterson and Selimgan put the two criteria is decomposed into 12 conditions, respectively is the "universal existence, to fulfill and realize, to have moral worth, not to belittle others, has the obvious' negative 'antonyms, trait, capable of measuring, significant, individual genius or prodigy, existing examples, can selectively deleted and to authorize some public organizations." Later, the classification work in a positive psychological quality content to undertake, Seligman and his team will be more than 12 criteria summarized into "whether has the cross cultural value, is itself has value, the three selection criteria as many entries selected positive mental quality content if they can cultivate".

\subsection{Ideological and political education}

Ideological and political education is a purposeful applied ideological influence on people, to change people's thinking, and guide people to action in the social practice activities [1]. In these practice activities, the transformation of educational object attitude is a very important factor, when the education objects change their attitude, then they accept the education. Further, they change mind and conduct practice activities. Attitude belongs to advanced psychological activity of human beings, it is refers to the form in the course of social practice and individual, the ready state and psychological tendency towards the object specific cognition, evaluation, judgment and behavior [2] in relation to attitude change theory, the influence and the application deeply, widely used is the Hovland's cognitive dissonance theory model of persuasion and Festinger.

Political ideologies in the United States vary considerably. Persons in the U.S. generally classify themselves either as adhering to positions along the political spectrum as liberal-progressive, moderate, or conservative. Modern American liberalism aims at the preservation and extension of human, social and civil rights as well as the government guaranteed provision of positive rights. It combines social progressivism and to some extent, ordoliberalism and is highly similar to European social liberalism. American conservatism commonly refers to a combination of economic liberalism and libertarianism, and to an extent, social conservatism. It aims at protecting the concept of small government, while promoting traditional values on some social issues.

For Chinese Ideological and political education, it is characteristic in current education system. And it is the main content of China construction of spiritual civilization, one of the main way to solve social contradictions and problems. Ideological and political education is very important, but also very difficult to do, especially under the condition of market economy, the ideological and political work China exist relatively weak condition, is not adapted to the modern requirements of social development. Many causes of ineffective ideological and political work, but one important reason is the long time we neglected the personality education and training. I thought, personality education is the foundation of Ideological and political education, without this foundation, ideological and political education is like rootless duckweed, always drifting in the human mind and can't go deep into the surface.

\section{THE IMPACT ON THE AUTHORITY OF IDEOLOGICAL AND POLITICAL EDUCATION TO CHANGE THE EDUCATION OBJECT ATTITUDE}

As a source of Ideological and political education, education will directly affect the change of education object attitude. Psychology experiment repeatedly proved, reputation of the people can trigger more attitude change than people without reputation. This "ability" or "qualification" reflect the authority of education object, determines the extent to educators as knows the right information. Therefore, ideological and political education should establish the authority, to influence the change of education object attitude. According to the particularity of Ideological and political education, ideological and political educators must first have a proactive stance, it must have a solid knowledge of political theory. In addition, advancing with the times in the information society background, learn new things, to accept new things, constantly update our concepts and methods of education, but also the important content of Ideological and political education form authoritative.

\section{THE POSITIVE ATTITUDE AND RICH KNOWLEDGE}

A positive attitude helps you cope more easily with the daily affairs of life. It brings optimism into your life, and makes it easier to avoid worries and negative thinking. If you adopt it as a way of life, it will bring constructive changes into your life, and makes them happier, brighter and more successful.

With a positive attitude you see the bright side of life, become optimistic, and expect the best to happen. It is certainly a state of mind that is well worth developing.

The Ideological and political education to educate the people, guide people, first he must of ideas, issues related to knowledge, understanding and recognition of the right, also is to have a positive attitude. Ideological and political education at 
present, positive attitude refers to adhere to Marx thought system, adhere to the socialist, communist beliefs, adhere to enhance people's awareness of the world, the ability to change the world. Ideological and political education through the theory of indoctrination, situational education as well as their own set an example by personally taking part, to guide the educated to abandon the backward ideas, establish a positive concept. If the educator's own position on the contrary and social development, this kind of negative, false ideas once taught the educated, if this idea just cognitive consistency of original and educated, then the firm more educated negative attitude; if this idea and the educated original cognitive conflict, educated by cognitive regulation may also change the original position, increase the new cognition.

Evaluation of the educators, often based on their rich knowledge degree. Education vast knowledge can make the educated have respect and sense of convincing sense, so as to form a cohesive force and centripetal force, to make the educated actively to accept education and management. The education object if that students have expertise, is the expert or the field of the industry, will accept him, this goodwill will generalization to his education in the spread of information, and then accept education, the occurrence of a change in attitude. At the same time, the content of education of science has the logic of great strength and the realistic strength, able to persuade through reasoning, direct access to the heart. In addition, the education to have the rich knowledge, a wide range of interests and hobbies can and educationists have more resonance, change the attitude of the educated. Especially the university is the birthplace of broadcasting advanced science and culture, is the high-level personnel training base, has a broad knowledge of the ideological and political education, to exert a strong influence and persuasion in college students, change the attitude.

\section{THE EFFECT OF CREDIBILITY IN THE IDEOLOGICAL AND POLITICAL EDUCATION TO CHANGE THE EDUCATION OBJECT ATTITUDE OUT OF TEXT}

Credibility, also referred to as "honest", "intention justice", the credibility that the educated extent to educators as to tell the real information, trustworthy. Information dissemination trustworthy, it is conducive to the dissemination of information and acceptance. The credibility of the ideological and political education, the degree of trust or educated to the education intention, will affect the strength of the educated to accept the education, the possibility of a change in attitudes. The establishment of Ideological and political education of credibility depends on the following two points.

\subsection{The Fair.}

IfThe fact proves, even if teachers have the authority, but if there is a loss of fairness and justice, the same can not be obtained by educators, change influence education attitude. The process of Ideological and political education, education fair fair performance make no exception in the treatment of the educated, respect, trust, educated, can make the educated on Ideological and political education and educators' favor and trust, strengthen the ideological and political education to accept the intention of education in accordance with the requirements, easy occurrence of attitude change. At the same time, the education embodies fairness, will influence education in influence character by environment for objective things attitude, develop scientific and impartial judgment consciousness and attitude change of consciousness.

\subsection{The authenticity of Educational content}

The content of Ideological and political education should have authenticity. The content of Ideological and political education reality depends both on the content itself, but also depends on certain education skills. The content itself authenticity requirement of Ideological and political education to transfer real, comprehensive, complete information, rather than intentionally cropped or shadowing. On this basis, the ideological and political education to master and use certain skills and methods, prove irrelevant to the educated guide attitude change and their own interests; to their comments attributed to the fact that, to make the educated are sure to explore the truth rather than personal gain; the abstract, direct information in education specifically, the emotional life of the material. In short, the ideological and political education should be good at the education content of aesthetic and visual, change the authenticity of the content of education to promote the influence character on environment by educated attitude.

Ideological and political education in the student education management process, positive selfconsciousness shown towards work; have the courage to overcome difficulties, never yield in spite of reverses tenacity and tenacity; stick to the truth, the principle and the bull by the horns of the resolute and determined to solve difficult problems; in the cool, calm, patient, self-control in the student, go; evoked potential culture shown in the process of education students energetic and rich emotion and so on, will touch and influence education, to make it become the educated themselves will at the same time, about the role of other educational factors play, which determines the direction and strength of the educated ideological and political attitudes. 


\section{CONCLUSION}

In terms of China's national conditions, ideological and political education plays very important role in school education. Our ideological and political education faces many new challenges. Attitude changing of ideological and political educator has the very large influence on the education result. In this paper, according to ideological and political educator, education information, education target and education environment, we will study the influence of the change from the ideological and political education object of educators, in order to improve the effectiveness of the ideological and political education.

\section{REFERENCES}

[1] Grove, A.T. 1980. Geomorphic evolution of the Sahara and the Nile. In M.A.J. Williams \& H. Faure (eds), The Sahara and the Nile: 21-35. Rotterdam: Balkema.
[2] Jappelli, R. \& Marconi, N. 1997. Recommendations and prejudices in the realm of foundation engineering in Italy: A historical review. In Carlo Viggiani (ed.), Geotechnical engineering for the preservation of monuments and historical sites; Proc. intern. symp., Napoli, 3-4 October 1996. Rotterdam: Balkema.

[3] Johnson, H.L. 1965. Artistic development in autistic children. Child Development 65(1): 13-16.

[4] Polhill, R.M. 1982. Crotalaria in Africa and Madagascar. Rotterdam: Balkema.

[5] Yang, Z.Y \&Wang, X.Y.1999. Ideological and political education psychology. Beijing: the capital normal university press.

[6] Ming, W.L.2010. Attitude change in the ideological and political education theories in the research on the application. The ideological and political education research. 23(2):34-39.

[7] Yang, C.Q.2007. Ideological and political educators: influence of educatees attitude change key factors. Ideological and political education research 20( 6): 1-8.

[8] Peng, D.2001. Common psychology. Beijing: Beijing normal university press.

[9] Zhou, Y.F.2002. Study on the ideological and political education in social transition, Tai Yuan University of Technology, 2002 (12): 79-82. 